\title{
CONTRIBUTIONS FROM THE ROCKY MOUNTAIN HERBARIUM. I.
}

AVEN NELSON.

Draba Yellowstonensis.-Annual, with stems of two kinds; the principal stem slender, erect, scape-like, $2-3^{\mathrm{dm}}$ high including the raceme,, simple or with long-peduncled racemes from the uppermost axil or axils; the one or more accessory stems from the base slenderer and shorter, ascending or erect: leaves mostly basal; root-leaves rosulate, from broadly linear to narrowly elliptic, sub-acute, entire or nearly so, $\mathrm{I}-2^{\mathrm{cm}}$ long; the few $(2-4)$ stem leaves mostly near the base, narrowly ovate, generally smaller than the root-leaves; pubescence on the leaves finely stellate, on the stems and peduncles sparse, the hairs more or less branching: racemes long in fruit, usually more than half the whole height of the plant: pedicels shorter than the capsules: flowers small; the sepals elliptic, obtuse, about half as long as the petals; the petals cuneate-spatulate, barely emarginate, white, $2-3^{\mathrm{mm}}$ long: capsule linear-oblong, tapering slightly to the apex, IO- $13^{\mathrm{mm}}$ long, finely pubescent; the style very short (less than $0.5^{\mathrm{mm}}$ long) but evident; the stigma 2 -lobed.

A very distinct species, having its nearest ally in $D$. montana Wats., a plant of more southern range.

Two collections of this were secured in Yellowstone pârk where it occurs or somewhat shaded, steep, moist slopes : no. 5687 (type), Undine falls, July 6; 'no. 5922, Yancey's, July i $7,{ }^{*} 1899$.

L epidium pubicarpum.-Annual, with slender vertical tap root; $-8 c^{\text {the stem }}$ paniculately branched from near the base, in well develo ped plants the branches similarly branched, only $9^{-1} 5^{\mathrm{cm}}$ high in luding the racemes, obscurely puberulent: leaves small, glabrous ${ }_{\mathrm{v} f}$ or nearly so, linear or somewhat spatulate, acute, the broader $\mathrm{c}_{\mathrm{ch}}$ nes remotely cut-toothed: beginning to blossom when very smalifo, the fruiting raceme crowded: pedicels short, hardly so long asY the capsule: petals wanting, the sepals purplish: I9001 
capsule permanently finely pubescent, from broadly oval to orbicular; stigma sessile in the narrow shallow notch: cotyledons incumbent.

Most nearly allied to L. apetalum Willd., from which it differs in being lower and more divaricately branched from near the base, while $L$. apetalun has a stem simple at base and branched above. L. pubicarpum is not restricted below the flower cluster, since this is very short and the pedicels become gradually divaricate. Its puberulent capsules separate it at once from L. apetalum.

Two collections secured : no. 6235 , Nez Perces creek, Yellowstone park, July 30; no. 6793, Dwelle's, Mont., August 31, 1899.

Arabis densicaulis.-Biennial or possibly more enduring, the tap root producing several or more often numerous crowded stems from its crown: stems ascending, $3-5^{\mathrm{dm}}$ high (including the raceme), leafy only toward the base, simple or some of the larger ones sparingly branched, glabrous or slightly hirsute near the base: root-leaves crowded-rosulate, oblanceolate, shortpetioled, $2-3^{\mathrm{cm}}$ long, finely stellate-pubescent ; stem-leaves rather numerous, glabrous, broadly linear or tapering uniformly from a broadish base to an acute apex, auriculate-clasping, the lobes short: flowers small, the petals white or purplish, linear-spatulate, about $5^{\mathrm{mm}}$ long and nearly twice as long as the oblong sepals: the fruiting raceme very long, often two thirds of the whole length; the numerous pods arcuate and widely divaricate or sometimes drooping but not pendulous, $4-5^{\mathrm{cm}}$ long, about $2^{\mathrm{mm}}$ wide, valves obscurely I-nerved at base; the pedicels about $\mathrm{I}^{\mathrm{cm}}$ long: seeds oval, in one row, scarcely winged; the cotyledons oblique approaching incumbent.

The cotyledons seem to indicate this as a member of the section SIs BRINA (Syn. Fl. I : I59), but I am unable to find in any of the known s.pecic a close ally. It may be recognized easily by its numerous stems crow ded of the crowns, and by the numerous, widely divaricate, arcuate pods of the long, naked racemes.

The type specimens were secured on partly wooded, hard, gravelly, north slopes, near Undine falls, Yellowstone park, July 6, I899, no. 5680 .

Arabis fructicosa.- Similar in size and habit to the preceding, glabrous throughout except for some fine stellate poubescence at base: the stems even more numerous, with more diveryent 
bases: crown leaves less crowded, some of them sparsely dentate; the stem leaves oblong to ovate, the larger ones dentate: fruiting racemes shorter, the pods broader, scarcely arcuate, divaricate-ascending; the flowers larger as are also the seeds.

No other Arabis is known to me that has the habit of this. A single plant sometimes has fifty or more assurgent stems and forms a hemispherical mat several decimeters in diameter. In this respect the preceding species most nearly approaches it. The two were found in the same locality, but they are at once recognized as different.

The type is no. $568 \mathrm{I}$, Undine falls, July 6, 1899 .

Arabis lignipes. - Short-lived perennial, simple-stemmed or more rarely with two or three stems from the summit of the tap root; the woody base of the stem persistent, apparently of as many internodes as the plant is years old, leafless, more or less covered with the old petioles; the internodes variable, usually only $\mathrm{I}-3^{\mathrm{cm}}$ long, the whole forming a naked woody foot surmounted by the crown of rosulate leaves at the base of the herbaceous part of the stem; herbaceous stems ultimately $3-5^{\mathrm{dm}}$ high, beginning to blossom when quite low, erect, finely stellatepubescent below, glabrous upward, becoming smooth throughout in age : the rosulate leaves small and crowded, entire, minutely but densely stellate pubescent, narrowly oblanceolate, tapering to a short petiole, $\mathrm{I}-2^{\mathrm{cm}}$ long ; the stem leaves numerous, sessile, almost linear, tapering to an acute apex from an auricular sagittate base, slightly longer than the rosulate leaves: raceme crowded in anthesis, open in fruit: pedicels sharply deflexed except in the youngest buds, at first minutely pubescent as are also the sepals, $5-7^{\mathrm{mm}}$ long : petals purplish or sometimes white, narrowly spatulate, $5-6^{\mathrm{mm}}$ long, nearly twice as long as the sepals : pod pendent, straight or curved, smooth, I-nerved, $6-8^{\mathrm{cm}}$ long, about $2^{\mathrm{mm}}$ broad: seeds in one row, broadly oval, scarcely wing-margined, about $\mathrm{I}^{\mathrm{mm}}$ long.

This finds its nearest ally in $A$. Holboellii Hornem., from which its naked woody foot, its invariably simple stems, its smaller entire leaves, and its perennial character separates it.

The following collections of it were secured on dry, sandy or stony bottom lands in Yellowstone park : no. 5503 and 5505, Madison river, June 23, I900; no. 5583 , Glen creek, June 30 , I900. 
Arabis pendulocarpa.-Perennial (probably short-lived), a short, simple or branching, woody caudex surmounting a slender tap root : stems I-3, only one from each crown, simple, ascending, rather weak, about $2^{\mathrm{dm}}$ high, nearly glabrous except at the base which is whitened with simple or branched matted hairs : leaves all entire, crowded on the crowns which are also covered with the remains of those of former years, closely and finely stellate pubescent, narrowly oblong to elliptic, tapering into a short petiole; the stem-leaves crowded toward the base, linear-oblong, sessile, not auriculate, $5^{-10^{\mathrm{mm}}}$ long, usually longer than those of the crowns: flowers few, small, nearly erect at anthesis but the siliques soon pendent: pedicels $6-8^{\mathrm{mm}}$ long, glabrous or nearly so: petals white or tinged with purple, about $5^{\mathrm{mm}}$ long, distinctly longer than the sparsely hairy sepals : pods $4-6^{\mathrm{cm}}$ long, about $2^{\mathrm{mm}}$ wide; the seeds narrowly wing-margined.

The key of the Synoptical Flora throws this into close proximity to $A$. pulchra Jones, but it is probably more nearly allied to $A$. Holboellii Hornem.

It occurs among the rocks on exposed or partly wooded hilltops. Secured twice, only in Yellowstone park: no. 5504, Madison river, June 23, ${ }^{8} 899$; no. 5728, Yellowstone river near Junction butte, July 9, I899.

Arabis elegans. - A tall biennial from a vertical tap root, 6- $\mathrm{IO}^{\mathrm{dm}}$ high: stem simple and strict (rarely a branch or two from the base), a pubescence of branched hairs below, becoming glabrate upward, leafy up to the inflorescence: leaves crowded on the lower part of the stem but not rosulate at the base, mostly entire, more rarely some of them remotely dentate, finely pubescent or the uppermost almost glabrous; the lower oblanceolate, petioled, passing into the oblong-linear, sessile, auriculate ones of the middle stem; the upper gradually smaller, linear, sagittate-clasping: raceme either few- or manyflowered; flowers rather large, from deep purple to almost white, petals almost twice as long as the pubescent sepals; buds erect but drooping in anthesis; pedicels ciliate, in fruit ascending, less than $1^{\mathrm{cm}}$ long, bearing divaricate, drooping, or variously curved and twisted pods: pods very slender, $5-8^{\mathrm{cm}}$ long, $\mathrm{I}-2^{\mathrm{mm}}$ wide. 
This species bears in its habit a marked resemblance to A.confinis Wats., but its narrower pods, which are not beaked, the shorter pedicels, and less glaucous appearance will aid in distinguishing it from its eastern ally.

It is of frequent occurrence in the open woods on moist slopes. No. $560 \mathrm{I}$, Mammoth hot springs, June 30 ; nos. 5676 and 5680 , Undine falls, July 6,1899 , the latter being the type number.

Arabis divaricarpa. - In habit resembling the preceding, possibly sometimes perennial, 4-6 $\mathrm{dm}$ high, glabrous except on the rosulate root-leaves, somewhat glaucous, more or less tinged with purple throughout : root-leaves petioled, slenderly oblanceolate, crowded on the crowns, the pubescence minute and branched; the stem-leaves linear-oblong, sagittate-clasping, $\mathrm{I}-4^{\mathrm{cm}}$ long: inflorescence glabrous; the flowers purple to white, smaller than in the preceding: pedicels about $5^{\mathrm{mm}}$ long: pods uniformly divaricate ascending, straight, $3-5^{\mathrm{cm}}$ long, about $3^{\mathrm{mm}}$ broad, most of them conspicuously I-nerved from base to apex. Like the preceding species, I can compare it only to $A$. confinis, from
which it differs in its broader pod, shorter pedicels, mostly entire leaves which
on the stem are rather on the stem are rather acutely lobed at the base. The seeds also are quite different; in $A$. confinis small, narrowly oblong; in $A$. divaricarpa rather
large and nearly oval.

It was secured in two localities on the open, sandy hillsides overlooking Yellowstone lake, August 1899 , nos. 6352 and 6622 .

Viola Thorii._- Root mostly simple, semi-fleshy, rather large petioles $2-3^{\mathrm{cm}}$ long, broadly ovate, truncate at base or abruptly narrowed into the petiole, very coarsely and bluntly dentate, sparsely puberulent below or entirely glabrous, I $2-20^{\mathrm{mm}}$ long: peduncles usually surpassing the leaves, very sparsely puberulent, $2-4^{\mathrm{cm}}$ long: sepals linear-lanceolate, glabrous, $4^{\mathrm{mm}}$ long or reddish-brown about $\mathrm{I}^{\mathrm{cm}}$ long, glabrous, yellow, the two upper Viola atriplicifolia

Viola atriplicifolia Greene, which I have not seen, is evidently a close
ally, but the species and has nearly entire leaves proposed lacks the cinerous puberulence of that, the other, which also leaves in contrast with the hastate or lobed leaves of

The type specimens thickened or flattened petioles.

near the summit of the Thunderer, were secured on the moist, open slopes 
also been collected by Dr. Blankinship in Montana and in Yellowstone park, but I am unable to cite his numbers.

Epilobium Wyomingense.-Perennial, spreading by filiform remotely scaly subterranean shoots which end in ovoid winter bulblets with few fleshy scales: stems slender, 2-4 ${ }^{\mathrm{dm}}$ high, strictly erect, mostly simple, more rarely with slender, erect branches from the axils of the opposite leaves; wholly glabrous below, towards the summit of stems and branches (if any) an obscure puberulence: leaves thin and glabrous, linear, tapering from the middle to both ends, sub-acute, from $3-5^{\mathrm{cm}}$ long (rarely even $8^{\mathrm{cm}}$ long), $2-5^{\mathrm{mm}}$ broad, the uppermost not noticeably reduced, midrib evident, the lateral veins obscure, plane, or the margin barely revolute, opposite except the floral, the few $(4-7)$ pairs nearly equidistant, often shorter than the internodes; those of the branches similar: flowers several, erect, small; the calyx cleft nearly to the base; the petals white, ovate, deeply triangular-notched at apex, $3-4^{\mathrm{mm}}$ long, a little longer than the sepals: capsules linear, $4-7^{\mathrm{cm}}$ long, minutely cinereous-puberulent; the pedicels variable, from much shorter to even exceeding the capsule: stigma oblong or short-clavate, barely notched at apex: seeds numerous, fusiform, smooth, scarcely beaked; the coma white, persistent.

This species is not very closely allied with any of the species known to me, though in a few respects it suggests $E$. Oregonense gracillimum and $E$. glaberrimum. In the more essential characters it seems to be allied to $E$. palustre, from which its longer smooth leaves and smooth stems, and its smooth almost beakless seed separate it.

It occurs in dense patches, on the grassy, boggy banks of spring stream lets. Yellowstone park, no. 5902, Yancey's, July I6; no. 6428, near Snake river, August I 2, 1899.

Cryptanthe multicaulis.- Several to many stemmed from the crown of the vertical tap root; the stems rather slender, ciliatehirsute, erect from a mostly short-decumbent base, sparingly paniculate-branched above, $\mathrm{I}_{5}-2 \mathrm{O}^{\mathrm{cm}}$ high : leaves rather numerous, broadly linear, $2-3^{\mathrm{cm}}$ long, the unequal, whitish, hispid hairs with pustulate bases: spikes slender, moderately dense even in fruit: sepals setose-hispid, the stouter setae yellowish, the 
midrib not evidently thickened, very narrowly lanceolate-acuminate, about $5^{\mathrm{mm}}$ long: nutlets obscurely roughened under a lens, ovate with sub-acute apex, less than $2^{\mathrm{mm}}$ long, the narrow groove forked at base but without conspicuous open areola, similar, usually only three maturing.

This species is allied to C. Pattersoni and to C. ramulosissima. In habit it is intermediate between them, but in floral and fruit characters it differs essentially from both. 1899.

The type number is 6440 , from Snake river, Yellowstone park, August I 3 ,

CRYPtanthe Affinis flexuosa.-Evidently allied to $C$. affinis, but a larger plant, $3-5^{\mathrm{dm}}$ high : stems loosely branched from near the base upward, the branches long and flexuous: leaves narrowly oblong, $2-3^{\mathrm{cm}}$ long: fruiting spike long and open: sepals lanceolate-acuminate, densely hispid at base, the tips mostly open and spreading, 6-8 $\mathrm{mm}$ long: nutlets mottled, smooth and shining, ovate-acute, about $2^{\mathrm{mm}}$ long, the ventral groove nearly closed, forked at the base but without areola.

This may prove worthy of specific rank, but until further material is secured it may best stand as a variety. The species, I think, occurs further toward the west and northwest only.

Secured in Jackson's hole, near Jackson's lake, August 17, 1899 . Mertensia amoena.-Root somewhat woody, more or less caudex few to several $(3-8)$, crowded, erect, closely covered with dead leaf-bases: stems one or more from each crown, simple, ascending, $I-2^{\mathrm{dm}}$ high, pubescent with short spreading or crisped hairs: crown-leaves oblong-lanceolate, sub-acute, glabrous below, softly hispid-pubescent above and on the margins, $4-7^{\mathrm{cm}}$ long, about one fourth as broad, on slender petioles which are usually longer than the blade: stem leaves rather crowded,
broadly linear or narrowly oblanceolate, sessile, $3-6^{\mathrm{cm}}$ long,
pubescence pubescence similar to that of the root-leaves; inflorescence half as ; calyx-lobes lanceolate, sparsely ciliate-hirsute, about the tube scarcely tube of the corolla; corolla about $\mathrm{I} 5^{\mathrm{mm}}$ long, the limb arcely longer than the campanulate limb, the lobes of bout half its length, crests inconspicuous; filaments 
broad as the anthers, inserted in the throat, the fret portion about as long as the anther; the style nearly as long as the corolla.

This is probably a part of the M. lanceolata (Pursh) DC. of Gray in Proc. Am. Acad. 10: 53, and of the Syn. Fl. $2: 201$, though it is very distinct from what Pursh and De Candolle understood by that species. The original seems to have been that glaucous, glabrous (at most slightly scabrous) plant which we know from the eastern slopes and foothills of the Rocky mountains, and which extends eastward toward the Missouri in the hill regions. That has rather thick fleshy leaves and has fewer stems. I have for years been familiar with it in southern and eastern Wyoming. During the season of 1899 Montana and northwestern Wyoming, where the species now proposed is common, came under my observation. It did not occur to me that anyone could possibly have called it $M$. lanceolata, so different are they in the field. $M$. amoena may be recognized by its cespitose habit, its hirsute (almost cinereous and never glaucous) leaves and stems, and the more crowded inflorescence, which in young plants reminds one of $M$. oblongifolia. It has the habit and leafiness of $M$. foliosa, and is more clearly distinct from $M$. lanceolata than $M$. Fendleri is from that species.

Collected at Monida, Mont., June I 5, no. 54I3; Glen creek, Yellowstone park, June 29 , I 899 , no. 5556 ; at both of which places it was abundant.

Solidago dilatata.-Perennial, from a woody root surmounted by a branched caudex bearing a few surculiferous branches which terminate in a fascicle of leaves: stems single from the crowns, simple, or branched above, rather stout, somewhat striate, glabrous, 4-6 $6^{\mathrm{dm}}$ high: leaves glabrous, conspicuously reticulate-veiny below, minutely scabro-ciliate on the margins; basal leaves oblong-spatulate to elliptic, tapering into a broad margined petiole which is sometimes as long as the blade, either closely or remotely serrate, mostly obtuse at apex, $8-15^{\mathrm{cm} l o n g}$; the stem leaves numerous, sessile, mostly small $\left(2-3^{\mathrm{cm}}\right)$ : inflorescence nearly glabrous (some ciliate straggling hairs), paniculately corymbose, either compact or quite open, the lower pedunculate branches leafy bracteate: heads numerous, slenderpediceled; the disk about $6^{\mathrm{mm}}$ high; involucral bracts in about three rows, the shorter outer ones very few, the two inner rows sub-equal, minutely ciliate on the margins, linear, most of them obtusish and slightly dilated upwards: rays 8-10, conspicuous; akenes short and lightly pubescent. 
This is to be compared with $S$. multiradiata scopulorum, but it is a much larger plant, with larger root-leaves and larger more open inflorescence. In being practically glabrous it also differs from that, and the upwardly cilated. bracts especially distinguish it.

It was abundant in loose gravelly soil in the open woods in the southern part of Yellowstone park, no. 6586, August 21, I899.

Machaeranthera superba.-Probably only biennial, very numerously branched from the crown of the slender tap root: stems decumbent at base and widely spreading, 8- $5^{\mathrm{cm}}$ long, each simple below, but paniculately corymbose as to the inflorescence, their purplish hue masked by a minute cinereous puberulence ; root-leaves (mostly wanting at flowering time) oblong-lanceolate, with minute spine-tipped teeth, cuspidate-obtuse, tapering into a slender petiole somewhat shorter than the blade, whole length $4-6^{\mathrm{cm}}$ : stem leaves rather numerous, broadly linear to narrowly oblanceolate, entire or remotely denticulate, the teeth and apex cusped as in the root-leaves, minutely and softly subcinereous (scarcely canescent), $3-5^{\mathrm{cm}}$ long, smaller in the inflorescence: heads moderately large, disk about $\mathrm{I}^{\mathrm{cm}}$ high, nearly as broad; bracts of the involucre oblong, acute, tips mostly erect, decidedly tinged with purple which is only slightly obscured by the thin puberulence, very rarely a few gland-tipped hairs on the margins: rays I2 (more or fewer), a deep blue (possibly sometimes varying to a purple), length mostly less
than $\mathrm{I}^{\mathrm{cm}}$. Of this species, which was submitted with a number of others, Dr. Greene
writes as follows: "A subalpine looking, too showy form of $M$. canescens.
But it cannot be refere But it cannot be referred to $M$. subalpina, however much it looks like it at
first glance." above species, of whince that was written I have given much study to both of the latter). I am satisfied I have typical specimens (the type number of the both, $\quad$ am satisfied that the species now proposed is amply distinct from M. canescens as understood (evidently) by Pursh, Nuttall, Gray, and
Greene is an essention up, some of its leaves are erect plant even though branched from the base green-tipped, the pube distinctly serrate or toothed, the bracts are evidently is more nearly allied to $M$. (as compared with $M$. canescens) pubescence. It $M$. canescens) showy heads and in the character of the $t$ is distinguished from it by the almost entire absence of viscid 
or glandular hairs, and from both by its less erect habit and by its broad, colored involucral bracts.

It occurred in the greatest abundance in one locality only, an open, sandy hillside near Yellowstone lake. The depressed, mat-like plants, with their relatively large, showy heads, were singularly attractive and invited the closest attention. The type number is 6337 , from the Thumb, August 6 , I899.

Erigeron Yellowstonensis.-Biennial, or probably many of the plants more enduring, with a strong vertical tap root: generally only one stem from the enlarged crown (more rarely $2-5$ ), simple, stout, striate, erect, paniculately branched as to the inflorescence, $3-6^{\mathrm{dm}}$ high, purplish, glabrate, the whitish hairs very straggling, obscurely granular (scarcely glutinous): leaves numerous, pubescence nearly wanting, similar to that of the stem; crown leaves oblanceolate, petioles $3-6^{\mathrm{cm}}$ long; lower stem leaves similar but with short winged petioles; upper leaves sessile, narrowly lanceolate, not much reduced, the short branches of the panicle from their axils; bracts small, linear: heads numerous, on rather slender peduncles; involucral bracts dark green, in two rows, subequal, very narrow, acuminate, shorter than the $\mathrm{I}^{\mathrm{cm}}$ high disk: flowers very numerous; rays filiform, purplish, only moderately numerous, largely concealed by copious pappus : akenes linear, appearing glabrous but sparsely pubescent under the microscope, less than $2^{\mathrm{mm}}$ long; the soft, dirty-white pappus nearly three times as long.

The E. Droebachensis Mueller (E. acris Droebachensis (Muel.) Blytt.) of Europe is unknown to me, but I cannot read the description of that into the plant now proposed as a species. Neither does it seem probable that any of the other usually accepted synonyms of $E$. Droebachensis represent this plant, for they also refer to European or arctic forms, except the E. glabratus of Hooker's Flora. The latter seems to have spatulate root-leaves, the cauline ones almost linear; a racemiform inflorescence, with very long lower pedun. cles, making an approach to a corymb; the pappus of a more yellowish hue.

This plant was found in abundance near Yellowstone lake, in the open pine woods, in loose sandy soil : nos. 6348 and 6615 , the Thumb, August
1899 .

ERIGERON MULTIFIDUS incertus.-Caudex densely cespitose; its branches comparatively long and woody, roughened with the 
old leaf-bases: stems usually two or more from each crown, rather slender, curved ascending or erect, I $2-18^{\mathrm{cm}}$ long, sparsely ciliate and obscurely granulo-puberulent, monocephalous : leaves crowded on the crowns, green and appearing glabrate but ciliate on the petioles and often on the blades, obscurely granulopubescent, simply three-parted, or more often each segment again three-parted ; ultimate segments linear-oblong, 4- $6^{\mathrm{mm}}$ long; petioles slender, $2-3^{\mathrm{cm}}$ long; stem leaves few $(2-4)$, bract-like, mostly linear, entire, the lower occasionally trifid: heads $8-12^{\mathrm{mm}}$ high, rays wanting (apparently sometimes a few filiform ones); disk flowers very numerous; involucre ciliate-pubescent and granulo-glandular under the longer hairs, bracts linear-acuminate, equaling the disk: mature akenes flattened, narrowly obovate, finely pubescent, about $2^{\mathrm{mm}}$ long; the soft pappus about twice as long as the akene.

This variety holds about the same relation to E. multifidus Rydb. (Fl. Mont. \& Y. N. P. 402) as the variety glabratus does to the same species. The two varieties resemble each other in habit and leaf outline. They are both glabrous in appearance, but only the one is wholly glabrous and the other is eradiate. The variety incertus differs from $E$. multifidus discoideus in its larger size, in being more glabrate, and in its cespitose caudex.

Nos. 5538 and 6066 from Yellowstone park belong here, as does also no. 2343 from Dome lake in the Big Horn mountains, 1896 . It occurs on dry stony hills and is fairly abundant.

Arnica Chamissonis longinodosa.-Stems single from horizontal rootstocks from which spring numerous, thick, fibrous roots, erect, $4-8^{\mathrm{dm}}$ high, the internodes long, usually $\mathrm{IO}-15^{\mathrm{cm}}$, much exceeding the leaves or rarely only equaling them: pubescence of two kinds, a short, dense, glandular puberulence (especially on the peduncle), and some scattering white crisped hairs (especially on the involucre): leaves $3-5$ pairs, denticulate ; the lowest pair oblong-oblanceolate, $6-\mathrm{IO}^{\mathrm{cm}} \mathrm{long}$, on slender least, rarely collected; the next lowest mostly obovate or narrower, tapering into a short margined petiole, variable in size, either shorter or longer than the lowest pair; the upper pairs 
ovate to oblong, $5^{-\mathrm{I}} 5^{\mathrm{cm}}$ long: heads $\mathrm{I}-3$, mostly single and then long-peduncled; if more, then from the axils of the uppermost leaves which are often much reduced, occasionally only one of the leaves and lateral peduncles developing; lateral peduncles equaling or even exceeding the terminal, $I^{\mathrm{dm}}$ (more or less) in length: heads large (if more than one somewhat reduced), disk $15-20^{\mathrm{mm}}$ high, $20-30^{\mathrm{mm}}$ broad; rays about twelve, $20-30^{\mathrm{mm}}$ long, 6-8 $8^{\mathrm{mm}}$ broad; involucral bracts $\mathrm{I} 4-2 \mathrm{O}$, lanceolate, acute, shorter than the disk: akenes striate, nearly linear, but tapering to the base, obscurely short-hispid on the angles, about $5^{\mathrm{mm}}$ long, equaling the sordid, sub-plumose pappus.

I have described this in detail, for I believe that it will ultimately be shown that this is a good species rather than a variety. The A.Chamissonis Less., from Unalashka, seems to be a much more pubescent plant, with narrower leaves and more pubescent akenes, the internodes, as compared with the leaves, relatively shorter.

The following numbers represent some of the collections of this species in Wyoming: 1702, $1785,357 \mathrm{I}$, and 6379, the last from Yellowstone park, August I899. M. E. Jones no. 5883 , from Utah, is this species.

Arnica Columbiana.-Perennial, $4-8^{\mathrm{dm}}$ high: stems rather stout, erect, striate, simple below, paniculately corymbose above, with some lanate white pubescence: root-leaves not known; stem leaves several (six or more pairs not counting the rameal), the lower apparently petioled, the middle and upper ample, sessile, clasping, entire, rather conspicuously nerved, oblong, sub-acute, finely pubescent below, obscurely so above, $8-14^{\mathrm{cm}}$ long, $3-5^{\mathrm{cm}}$ broad; rameal leaves and bracts ovate, the smaller ones acuminate: inflorescence an ample panicled

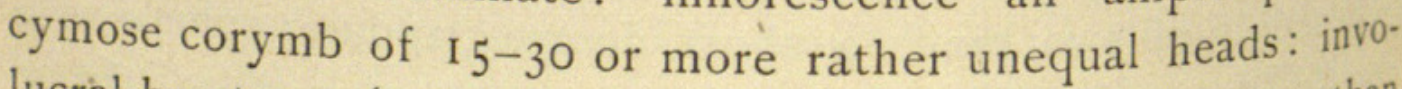
lucral bracts 20 (more or less), oblong, sub-acute, shorter than the disk: rays 12 or less, IO- $14^{\mathrm{mm}}$ long, $3-4^{\mathrm{mm}}$ broad: akenes small, 5-nerved, linear-subcylindric, tapering to a slender base, only about $3^{\mathrm{mm}}$ long, shorter than the sordid pappus.

Of this unusually distinct species I have seen but two specimens, both of which are in the herbarium of the Montana State College.

The type is Mrs. J. J. Kennedy's no. 24, Columbia falls, Mont., 1894 Mr. R. S. Williams' no. I049, from the same locality, June 14,1894 , is the 
same as to the larger specimen (on the sheet before me). Both were distributed as $A$. amplexicaulis Nutt., to which they bear but little resemblance. Mrs. Kennedy's specimens are included by Dr. Rydberg in his A. amplexifolia (Nutt.) of his Flora of Montana.

Arnica ocreata.- From slender horizontal rootstocks : stems slender, $3-4^{\mathrm{dm}}$ high, erect, very leafy, nearly glabrous, more or less finely granular-glandular, occasionally some straggling woolly hairs : leaves 6-Io pairs, ascending or erect, from broadly to narrowly lanceolate, entire, sub-acute, gradually smaller upward and becoming bract-like, all but the uppermost much exceeding the short internodes (even overlapping two or three of the internodes), the lowest petioled, the uppermost sessile: petioles slender, dilated at the base and connate, the pair forming an ocrea or sheath which in the lowest leaves is $2-3^{\mathrm{cm}}$ long, the sheath and petioles gradually shorter upward to about the middle of the stem where both become wholly absent: heads one to several; if three, corymbose, the two from the axils of opposite bracts; if more than three, mostly somewhat racemose from the axils of alternate bracts; terminal head largest, disk I0-I $2^{\mathrm{mm}}$ high, exceeding the oblong, obtusish bracts, about $\cdot 15^{\mathrm{mm}}$ broad; rays about $\mathrm{I}^{\mathrm{cm}}$ long; lateral heads somewhat reduced: pedicels variable, rather slender, very lightly woolly-pubescent : akenes nearly glabrous, lightly striate, somewhat flattened, narrow, tapering to the base, nearly equaling the soft pappus. This is in part, so far as specimens in the collections go, $A$. foliosa. It is
not the $A$. foliosa of Nuttall, which is probably a rarer plant, though collec-
tions of that are description and as may be and Gray's Flora N. A. (where gathered from Hooker's Flora and from Torrey Chamissonis) is a very different it was compared with $A$. montana and $A$. A. foliosa has the stout, strict habit of that, is tomentose pubescent, some(about five), the throughout, the leaves callous-denticulate, evidently nerved ocreata may be recognized atested-corymbose and the akenes hirsute. $A$. entire, rather narrowly lat at once by the characteristic disposition of its upward and the comlanceolate leaves. Owing to their diminution in size appearing early) the paratively long petioles of the lower (some of them disthe middle, while the strict leaves have the appearance of being crowded near 
This species occurs on wet bottom lands in the edges of copses of undershrub. Typical collections of it are nos. 766 and I I 95, Wind river, Wyoming, Aug. 1894, by Nelson; no. 5224, Shoshone lake, Aug. 1897, by Rydberg \& Bessey; no. 6403, Snake river, Aug. I 899, by Nelson \& Nelson; Silverton, Colo., July I 898 , by $C$. $S$. Crandall (distributed as $A$. longifolia).

Arnica polycephala.-Nearly allied to and much resembling A. longifolia Eaton, but larger than that species, forming larger and denser clumps, the stems very numerous: leaves lanceolate, less acuminate than in $A$. longifolia, glabrous or obscurely granuloglutinous: heads moderately large, very numerous (20-50) on each stem which is paniculately branched above.

This might possibly be considered only a variety, but it is ance distinguished from its ally by the absence of the fuberulence of that species, by the less acuminate leaves, and the several times more numerous heads.

It was found growing in great masses among the rocks of the slides, of the steep cliffs overlooking Snake river near the southern boundary of Yellowstone park. The type is no. 6422, Aug. I2, I899.

Arnica exigua.- Low, I-2 dm high, sub-cinereous hirsutepubescent throughout, with an obscure granular glutinosity beneath: stem erect, corymbosely paniculate-branched from the base upward; the branches ascending, often a pair from each node, each bearing one or two heads: leaves mostly lanceolate, acute; the two or three pairs on the main stem $5-8^{\mathrm{cm}}$ long, all sessile; those on the branches similar but smaller: heads of medium size, involucral bracts oblong, sub-acute, nearly equaling the disk which is IO- I $5^{\mathrm{mm}}$ high; rays in well developed heads twelve or more; akenes very narrow and tapering to the base, nearly glabrous.

This is a species of unusual habit. It has the appearance of a plant which has put out new shoots after being browsed off and stunted by some animal. An examination, both in the field and of the specimens collected, shows that this is not the case, and that this dwarfed plant is perfectly normal. It is an ally of $A$. foliosa Nutt., of which I at first suspected it being a deformed state. The habitat of the two is different. A. foliosa is found on the fertile soils of
wet bottom lands.

The specimens of $A$. exigua were secured on the higher, dry sandy bluffs and ridges overlooking Yellowstone lake. The type is no. 6940, Aug. 24,
I899. 
Arnica caespitosa.-Low ( $\left.\mathrm{I}-2^{\mathrm{dm}}\right)$, matted, sometimes forming beds several decimeters across, with moderately large woody horizontal rootstocks from which spring numerous thick fibrous roots, the whole forming a dense turf: the numerous stems erect, sparsely short-lanate as is also the base of the involucre: leaves nearly glabrous or sparsely ciliate-woolly, three or four pairs on the stems and some fascicled ones on the sterile crowns; crown leaves mostly oblanceolate, petioled, $4-7^{\mathrm{cm}}$ long (including the petiole); basal stem leaves very small (often wanting), obovate as also the next larger pair; upper leaves lanceolate: heads one to five, large for the size of the plant, mostly three (a terminal one and a pair from the uppermost axils); pedicels moderately stout, $2-5^{\mathrm{cm}}$ long: involucres turbinate; bracts linear-oblong, sub-acute, almost equaling the disk; rays 8-10, ascending, rather broad: akenes linear, whitepubescent, about $5^{\mathrm{mm}}$ long, equaling the white, glistening pappus.

An excellent species of nearly alpine stations; occurring in patches on nearly naked, rocky slopes. It may be recognized by its cespitose habit and dense root-system, its turbinate head (the rays are ascending also), and the white-pubescent akenes.

Collections of it are no. 5785 , Druid peak, Yellowstone park, July I2 ; no. 6717 , Teton mountains, Aug. 16, 1899.

LARAMIE, WYo. 


\section{$2 \mathrm{BHL}$ Biodiversity Heritage Library}

Nelson, Aven. 1900. "Contributions from the Rocky Mountain Herbarium. I." Botanical gazette 30(3), 189-203. https://doi.org/10.1086/328033.

View This Item Online: https://www.biodiversitylibrary.org/item/95192

DOI: https://doi.org/10.1086/328033

Permalink: https://www.biodiversitylibrary.org/partpdf/223064

\section{Holding Institution}

Missouri Botanical Garden, Peter H. Raven Library

\section{Sponsored by}

Missouri Botanical Garden

\section{Copyright \& Reuse}

Copyright Status: Public domain. The BHL considers that this work is no longer under copyright protection.

This document was created from content at the Biodiversity Heritage Library, the world's largest open access digital library for biodiversity literature and archives. Visit BHL at https://www.biodiversitylibrary.org. 